\title{
PENCIPTAAN TOKOH ROSE THOMAS DALAM NASKAH PERANGKAP KARYA EUGENE O'NEILL TERJEMAHAN FARIED. ABE
}

\author{
Nindya Pramesti \\ Institut Seni Indonesia Yogyakarta
}

\begin{abstract}
Abstrak: Naskah Perangkap karya Eugene O’Neill (terjemahan Faried W. Abe) bercerita tentang kondisi ketidakadilan yang dialami oleh perempuan. Tokoh Rose Thomas dalam naskah tersebut merupakan seorang pelacur muda berusia 22 tahun, memiliki bayi, dan mengidap TBC. Karya pemeranan ini menggunakan teori akting realis Stanislavski untuk menghadirkan tingkah laku manusia secara wajar diatas panggung. Proses penciptakan karakter tokoh dilalui dengan langkah: membedah naskah; membuat biografi tokoh berdasarkan data dalam naskah; dan kemudian latihan pemeranan realis dengan pemeran tokoh pelangkap lain.
\end{abstract}

Kata kunci: Rose, Eugene O’Neill, Pelacur, TBC, Kekerasan, Perangkap, Realis, Stanislavski

\begin{abstract}
Perangkap, a playscript by Eugene O'Neill (translation of Faried W. Abe) tells the story of the conditions of injustice experienced by women. Rose Thomas in the script is a young prostitute aged 22 years, had a baby and has tuberculosis. This role play uses Stanislavski's realist acting theory to present human behavior naturally on stage. The process of creating character traits is passed through the steps: dissecting the script; make biographies of figures based on data in the script; then practice the realist role-playing with the cast of the other trapping characters.
\end{abstract}

Key words: Rose, Eugene O'Neill, The Web, Prostitute, Tuberculosis, Violence, Realist, Stanislavski

\section{Pendahuluan}

Salah satu permasalahan yang menjadi perhatian besar masyarakat akhirakhir ini, bahkan juga sudah menjadi masalah internasional dan sangat meresahkan adalah tindak kekerasan terhadap perempuan. Hal ini seringkali dianggap suatu kejadian yang terbelakang atau bahkan dapat dikatakan tidak menarik. Padahal jika dilihat dari kenyataan yang selama ini terjadi, tindak kekerasan terhadap perempuan merupakan ancaman terus menerus bagi perempuan dimanapun di dunia.

Kekerasan terhadap perempuan bisa terjadi dimana saja, dilakukan oleh siapa saja, dan kapan saja. Tentu saja hal ini merupakan tindakan yang sangat menyakiti atau membuat penderitaan baik itu secara fisik, seksual, dan psikis yang mengakibatkan trauma pada perempuan yang menjadi korban. Tidak jarang ketika seorang perempuan mengalami kekerasan akan berlangsung dalam waktu yang lama dan terus menerus, serta berdampak pada kehidupan yang mereka jalani selanjutnya.

Naskah Perangkap karya Eugene O'Neill, merupakan naskah yang relevan untuk menghadirkan situasi ini ke tengah masyarakat. Naskah ini mengisahkan kehidupan kaum marjinal di Amerika 
Serikat, dimana didalamnya ada seorang tokoh wanita bernama Rose Thomas yang terperangkap dalam ketertindasan namun ia tidak kuasa untuk pergi menyelamatkan dirinya sendiri. Setiap hari ia harus hidup dalam tekanan bersama anaknya dan bekerja sebagai pelacur jalanan. Penderitaan dan ancaman yang dialaminya seakan tidak ada habisnya. Kondisi semacam ini banyak terjadi di sekitar kita. Perempuan sering diperlakukan secara tidak wajar, padahal hal tersebut tidak bisa dibenarkan walau dengan alasan apapun.

Bagi seorang aktor, memerankan tokoh Rose Thomas merupakan sebuah tantangan tersendiri. Pertama, tokoh Rose Thomas ini memendam konflik batin yang sangat berat, banyak hal yang berkecamuk dalam pikirannya. Selain itu secara fisik pun dia tidak sedang baik-baik saja. Dia sering mengalami kekerasan dan sedang menderita penyakit TBC yang parah. Seseorang yang mengidap penyakit TBC tentu akan memiliki beberapa karakteristik yang khas seperti gesture, cara berbicara, dan kebiasaan yang sering dilakukan. Hal ini tentu akan menambah kerja aktor dalam menghadirkannya. Misalnya gesture seorang penderita TBC akan berbeda dari orang kebanyakan karena ia akan selalu merasa kedinginan. Dari cara berbicara pasti akan tersendat-sendat oleh batuknya yang terus muncul serta kebiasaan menggunakan masker agar orang-orang disekitarnya tidak tertular.

Secara karakter dan latar belakang tentu saja sangat berbeda antara pribadi aktor dan tokoh itu sendiri. Karakter bisa disebut tokoh, karena karakter ini berpribadi, berwatak, dia memiliki sifatsifat karakteristik dengan tiga dimensional yaitu Fisiologis, Sosiologis, dan Psikologis (Harymawan, 1998).

Kedua, ketertarikan aktor juga muncul pada naskah Perangkap karena karakter Rose Thomas disini sangat kuat, syarat akan kelemahan namun juga ketegaran, sangat menandai kehidupan yang biasa dialami oleh wanita, bahkan di zaman yang sudah modern seperti sekarang ini. Tokoh Rose Thomas adalah gambaran wanita yang sangat tegar ditengah penderitaan yang dialaminya. Ia harus berjuang mengurus anaknya, juga mencari nafkah untuk memenuhi kebutuhan hidup serta tuntutan dari seorang laki-laki bernama Steve yang bahkan bukan suaminya sendiri. Kekerasan fisik pun dijadikan senjata ketika Rose Thomas hanya ingin memperjuangkan sedikit haknya, padahal ia juga harus bertahan ditengah penyakit TBC yang dideritanya. Pengidapnya dapat merasakan aneka gejala sepertu batuk yang berlangsung lebih dari 3 minggu, demam, berat badan turun tanpa sebab, keringat malam, senantiasa lelah, nafsu makan berkurang, dan dahak bebercak darah. Tentu setelah didapati halhal tersebut diatas aktor harus bisa memperagakannya lewat peran yang ia mainkan.

Sebagai tokoh utama, Rose muncul dari awal hingga akhir peristiwa. Naskah ini mempunyai tingkatan emosi dan suasana yang beragam, alur peristiwanya pun cukup rapat untuk membuat penonton tidak beranjak dari tempat duduknya hingga pertunjukan berakhir. Memerankan tokoh Rose Thomas menjadi tantangan tersendiri, bukan hanya dalam segi pemeranan tetapi aktor juga memikirkan tentang bagaimana efek bagi penonton setelah menonton pementasan ini.

Ketiga, naskah Perangkap dipilih karena merupakan naskah realis. Dalam pementasan kali ini aktor ingin beraksi secara wajar dengan membawakan naskah yang mengangkat konflik dalam kehidupan sosial. Menurut seniman realisme, sesuatu harus dilihat atau dilukiskan menurut keadaan yang sesungguhnya. Dengan demikian mereka mengamati sesuatu dengan kacamata objektif, tidak boleh dengan sengaja diindah-indahkan atau tidak boleh pula dibuat lebih buruk (Anwar, 2005). Saat ini, banyak aktor yang beraksi hanya sekedar untuk terlihat indah di mata penonton tanpa memperhatikan kedalaman karakter pada tokoh yang diperankannya. Akting bukan semata-mata berbuat sesuatu 
karena kita mampu melakukannya, tetapi juga berbuat atau berlaku untuk dilihat orang lain atau ditonton orang banyak (Anirun, 1998).

Seorang aktor pasti ingin menjadi yang terbaik di mata penonton, tetapi yang menjadi persoalan terbesar adalah kemampuan seorang aktor untuk menghadirkan karakter tokoh yang ia perankan dalam naskah secara utuh. Seorang aktor adalah kebalikan dari seorang bintang. Modal seorang aktor bukanlah wajahnya yang cantik atau potongannya yang tampan, tapi kesanggupan untuk menghidupkan dan menjiwai suatu tokoh di depan penonton (Bolelavski, 1960). Menurut Gassner dalam drama realis membutuhkan kemampuan akting tingkat tinggi, "The Realist cannot allow the individual character to expose his inner processes by means of soliloquis and asides nor is he free to shape the play to suit the character's state of mind" (Endraswara, 2014). Banyak aktor melakukan manipulasi bentuk berusaha menghidupkan dan menjiwai karakter tokoh dengan menampilkan keindahan bentuk seperti bahasa tubuh, warna suara maupun cara bicara tanpa menggali sisi yang terdalam dari karakter terebut. Dan karena aktor dituntut untuk menciptakan suatu citra ketika ia berada di panggung, bukan hanya memamerkan dirinya kepada khalayak, ini menjadi suatu keharusan bagi kita semua. Dengan kata lain, semua aktor yang adalah seniman, pencipta citra, yang harus menggunakan perwatakan yang memungkinkan mereka menjadi 'jelmaan' dalam melaksanakan pemeranan mereka (Stanislavski, 2008).

Naskah Perangkap karya Eugene O'Neill ini menuntut aktor untuk mengetahui bagaimana seluk beluk mengenai tokoh yang akan diperankannya. Seorang aktor harus mempelajari karakter manusia lain yang sama sekali berbeda dengan dirinya. Dengan cara ini, maka akan terungkap bagaimana latar belakang, kebiasaan tokoh, apa yang sedang menjadi pikirannya, dan hal-hal lain yang menjadi acuan aktor untuk menjadi tokoh yang diperankan.

Aktor dalam pemeranan ini menggunakan metode akting realis Stanislavski. Akting realis, yakni akting yang berusaha menyuguhkan tingkah laku manusia melalui diri si aktor dari hasil mengerti karakter yang dimainkannya. Menciptakan sesuatu diatas panggung seperti "kenyataan" yang ada. Menciptakan ilusi diatas panggung, seolah-olah penonton menyaksikan apa yang terjadi dalam kehidupan sehari-hari. Ilusi tentang kenyataan yang terdapat dalam masyarakat yang kemudian "dipindah" diatas panggung. Dengan harapan, realitas dalam naskah ini yang bersumber pada kehidupan sehari-hari dapat tergambar secara jelas bagi penonton.

Uraian latar belakang dari naskah Perangkap karya Eugene O'Neill dalam fokus penciptaan tokoh Rose Thomas ini menghasilkan rumusan penciptaan sebagai berikut :

a. Bagaimana menganalisis karakter tokoh Rose Thomas dalam naskah Perangkap karya Eugene O'Neill?

b. Bagaimana memerankan tokoh Rose Thomas dalam naskah Perangkap karya Eugene O'Neill dengan teori akting Stanislavski?

Melalui sebuah gagasan kreatif seorang kreator memunculkan motivasinya untuk menjawab mengapa karya tersebut harus lahir. Adapun tujuan dari proses pengkaryaan ini adalah menciptakan karakter tokoh Rose Thomas dengan membedah naskah terlebih dahulu, membuat biografi tokoh yang didasarkan pada temuan-temuan dalam naskah. Untuk dapat sampai kepada sasaran kita, mencari identitas peran selengkap atau semaksimal mungkin kemudian memerankannya dengan melakukan metode latihan akting realis dengan tokoh pendukung lainnya. Seperti karakterisasi, gesture, vokal, rasa, dan unsur-unsur pemeranan lainnya. 


\section{Teori}

Bermain teater membutuhkan pembelajaran mengenai psikologis manusia dalam berperan. Pemain teater adalah orang yang mempergunakan tubuh dan perasaannya untuk mengekspresikan karakter orang lain. Memerankan karakter manusia baru didalam diri harus memiliki pengetahuan psikologis manusia dalam suatu peristiwa yang dilaluinya. Aktor menggunakan teori keaktoran yang sesuai dengan kebutuhan teater realisme sebagai bentuk teater yang berbicara tentang persoalan individu. Bentuk teater realisme merupakan bentuk drama tertutup yang memandang ke dalam. Seorang aktor harus mencipta tokoh yang konsisten dengan emosinya sendiri dan rasa tentang identitas pribadinya (Harrop \& Eipstein, 2010). Mempelajari pemeranan realis harus memiliki pengetahuan psikologis untuk menghayati sebuah peran yang akan membantu menciptakan kehidupan rohaniah manusia (Stanislavski, 2007). Tanpa pengetahuan aktor hanya memainkan bentuk tokoh tanpa isian. Sedangkan modal seorang aktor adalah kesanggupan untuk menghidupkan dan menjiwai suatu watak didepan penonton.

Suatu akting tampak bermakna hanya ketika ia nampak nyata dan realitas merupakan fungsi suatu sebab (Mitter, 2002). Kesanggupan yang dimaksud adalah merelakan jiwa dan raga untuk memerankan manusia baru didalam diri. Untuk memerankan tokoh manusia baru didalam diri membutuhkan pengetahuan tentang tabiat, perilaku dan cara hidup tokoh. Tidak mungkin membawakan peranan hidup tanpa pengetian tentang tabiat manusia (Harrymawan, 1988). Ketika aktor mengerti dan melakukan cara hidup tokoh dengan yakin maka akan terlihat suatu kesungguhan dimata penonton. Aktor perlu menghadirkan karakter yang benar diatas panggung. Karakter manusia yang hidup dan bergerak sewajarnya manusia. Kepercayaan aktor terhadap aktingnya sendiri adalah jalan menuju kebenaran (Mitter, 2002).
Kebenaran yang dimaksud adalah kebenaran yang dapat dipercaya penonton. Aktor melakukan dengan bersungguh sungguh dan mengikhlaskan dirinya untuk menjadi manusia baru dalam pentasnya.

Melalui pendekatan akting realisme tokoh Rose Thomas akan didapat secara utuh. Aktor menggunakan teori Stanislavski karena pada naskah Perangkap karya Eugene O'Neill membicarakan persoalan realitas hidup. Dalam hal ini penonton bisa lupa, bahwa dunia luar yang ada di atas pentas sesungguhnya hanyalah teater (Anwar, 2005). Pemeranan realis merupakan ilusi realita yang ditampilkan seolah-olah benar dan dapat dipercaya kebenarannya (Stanislavski, 2007). Bermain benar artinya bermain tepat dan masuk akal bahkan masuk kedalam hidup tokoh tersebut dengan memainkan logika tokoh, perasaan serta fikirannya. Pendapat tersebut menyimpulkan bahwa berlakon bukanlah sekadar kepura-puraannya saja, namun juga mendalami kehidupan tokoh dengan cara menemukan kebiasaankebiasaan yang mungkin tokoh lakukan sehingga menjadikan seorang aktor cerdas dalam memahami manusia yang diperankannya. Teori akting Stanislavski sangat dibutuhkan untuk pemeranan realis tokoh Rose Thomas dalam naskah Perangkap karya Eugene O'Neill yang akan dipentaskan.

Kemudian, setelah melakukan pencarian dan memahami karakter tokoh maka aktor menyatukannya dengan pengalaman-pengalaman emosi yang pernah dialami. Metode ini juga dijelaskan oleh Stanislavski (2007) bahwa:

"Secara garis besar aku telah menjelaskan pada kalian hari ini apa yang bagi kita bersifat pokok. Pengalaman membuat kita yakin, bahwa hanya seni yang berendam dalam pengalaman hidup manusia, yang dapat memproduksikan secara artistik warnawarna dan kedalaman hidup yang tidak mudah dipahami. Hanya seni seperti ini yang dapat memukau penonton selengkapnya dan membuatnya mengerti serta menghayati secara rohaniah 
kejadian-kejadian diatas panggung, yang dapat memperkaya kehidupan batinnya, dan yang bisa meninggalkan kesan-kesan yang tidak akan pudar oleh waktu."

Teori akting realis akan tercipta dengan adanya identifikasi dari karakter yang akan diperankan, sementara tingkah laku akan berkembang dari situasi-situasi yang telah dituliskan oleh si penulis naskah, tentunya dengan cara memahami keseluruhan isi naskah agar tingkah laku dari karakter bisa tercipta dan berkembang.

\section{Metode Penciptaan}

Metode penciptaan adalah cara yang ditempuh untuk memaksimalkan unsurunsur penting dalam memerankan sebuah tokoh. Unsur-unsur tersebut diantaranya adalah sukma, tubuh, vokal, serta penunjang yang lainnya. Tahapan yang akan ditempuh untuk dapat memerankan tokoh Rose Thomas dalam naskah Perangkap karya Eugene O'Neill diantaranya:

\section{a. Analisis Karakter}

Aktor harus mampu menciptakan karakter yang dapat dipercaya untuk menjalankan aksi dalam naskah (Sitorus, 2003). Tahap awal dalam mencipta peran adalah analisis tokoh, dalam tahap ini aktor akan menganalisis secara detil tentang beberapa hal yang berkaitan dengan karakter tokoh. Analisis ini menyangkut ciri, kebiasaan, sifat, dan hal-hal mendetail lainnya yang mendukung untuk memerankan tokoh. Untuk menciptakan karakter Rose Thomas agar dapat dipercaya dan diyakini sebagai tokoh yang memiliki kehidupan dengan konflik tersendiri, aktor haruslah memiliki keterampilan dalam menemukan karakter-karakter tersebut dan menyusunnya agar menjadi satu kepribadian yang utuh.

\section{b. Membuat Rancangan Tokoh \\ Pada tahap ini, aktor harus membuat} rancangan dari tokoh yang akan dimainkan. Pada pemeranan tokoh Rose Thomas, aktor harus mencari semua informasi tentang tokoh tersebut hingga sedetail mungkin.Setelah menganalisis, aktor menyusunnya menjadi sebuah biografi agar dapat mewujudkan tokoh dengan utuh. Aktor bisa mempelajari beberapa referensibuku psikologi untuk membantu proses penciptaan tokoh. Hal ini perlu dilakukan sebab tujuan utama dari studi psikologi kepribadian adalah mempelajari manusia secara total atau menyeluruh (Koswara, 1991).

\section{c. Observasi}

Obseravsi bertujuan untuk memperkaya referensi dalam pemeranan tokoh dan menemukan karakteristikkarakteristik khusus yang tidak biasa ditemukan pada orang kebanyakan. Misalnya bagaimana mengetahui gesture seorang pelacur jalanan, orang dengan penyakit TBC, dan lain sebagainya.

\section{d. Melatih Bahasa Tubuh}

Bahasa tubuh seorang tokoh akan berbeda dengan bahasa tubuh diri sendiri. Bahasa tubuh tokoh akan timbul karena perasaan yang tokoh miliki dengan kesinambungan masalah yang tokoh hadapi. Hal tersebut harus dilatih agar aktor mempunyai motivasi dalam bergerak. Rose Thomas adalah perempuan yang sedang mengalami banyak tekanan, oleh karena itu pergerakan yang dilakukan Rose harus melewati proses berfikir dan merasakan tokoh Rose yang mendorong motivasi untuk bergerak sebagai tokoh. Setiap aktor dinilai baik atau buruk dari sejauh mana ia bisa memakai gerak tangan dan isyarat tubuh yang lain untuk berkomunikasi secara efektif (Pease, 1993).

\section{e. Melatih Vokal}

Suara adalah kendaraan yang mengantarkan imajinasi penonton (Anirun, 1998). Maka latihan vokal sangat penting untuk melatih volume, artikulasi, dan intonasi dalam berdialog agar informasi dari para aktor yang berperan dapat tersampaikan dengan baik pada penonton. Banyak interpretasi salah tentang kualitas 
vokal yang baik menurut pemahaman para aktor. Mereka sering menganggap bahwa kualitas vokal yang baik ialah cara pengucapan dialog yang keras dan nyaring agar suara terdengar oleh seluruh penonton. Akan tetapi, persepsi tersebut salah karena kualitas vokal yang baik ditentukan pengucapan dialog yang jelas, bukan hanya keras (Pratiwi \& Siswiyanti, 2014).

\section{f. Latihan "Pengekangan" Gesture}

Pemahaman atas gesture atau bahasa tubuh haruslah di dahului dengan membaca buku-buku tentang kepribadian dan bahasa tubuh itu sendiri, kemudian dari situ kita dapat memahami bahwa setiap gesture memiliki arti tertentu. Untuk memerankan tokoh Rose Thomas, tentu aktor harus melatih gesture-gesture tertentu seseorang yang sering mengalami kekerasan secara fisik dan psikis, serta disaat yang bersamaan juga menderita penyakit TBC. Tentu saja disesuaikan dalam relevansinya dengan teori akting realisme. Hal ini dijelaskan oleh Stanislavski (2007). bahwa:

\footnotetext{
"Selain gesture, aktor juga melakukan banyak gerak yang tak dia sengaja dalam upaya menolong diri melewati titik-titik sulit dalam permainannya. Gerak-gerak itu mungkin menimbulkan pengaruhpengaruh emosi atau tampilan fisik dari emosi-emosi yang tidak dialami oleh aktor yang dangkal. Gerak-gerak macam itu berupa kejang-kejang, ketegangan otot berlebihan yang tidak perlu sekaligus merugikan, yang sebetulnya dimaksudkan untuk memudahkan munculnya emosi-emosi teatrikal. Tapi gerak-gerak itu hanya membopengkan peran, melainkan juga mengganggu pengekangan dan pengendalian diri serta kewajaran dan kesejatian si aktor ketika berada di panggung. Dengan latihan pengekangan gesture akan dirasakan dirasakan ekspresi fisik membaik. Diimbangi intonasi suara, kelenturan ekspresi wajah sebagai sarana komunikasi yang lebih tepat" (Stanislavski, 2007).
}

\section{g. Olah Rasa}

Sukma yang terlatih dengan baik akan mudah dimasuki setiap emosi tokoh, disinilah fungsi dari latihan olah rasa.

\section{h. Isolasi diri}

Isolasi diri adalah latihan untuk menganggap bahwa didalam tubuh aktor terdapat manusia baru yang harus aktor perankan dan aktor harus selesai menjadi dirinya sendiri. Latihan isolasi diri dapat membuat aktor menjadi tokoh yang baru. Isolasi diri adalah latihan dimana kita berusaha mengenali diri pribadi secara mendetail lalu menyimpan sejenak semua itu kemudian kita secara perlahan memasukkan karakter tokoh ke dalam pikiran kita, tubuh kita dan rasa kita.

i. Menghayati peran

Menghayati peran adalah memberikan hidup kita kepada tokoh, menyadari betul setiap nafas, pikiran dan perasaan kita adalah perasaan tokoh, mengurangi keinginan-keinginan pribadi sebagai aktor sehingga tokoh akan muncul dalam diri kita secara alami.

\section{Pembahasan}

\section{a. Konsep Pemeranan}

Karakter atau tokoh adalah penggerak alur yang menyampaikan pesan dalam sebuah drama. Penokohan adalah proses penampilan 'tokoh' sebagai pembawa peran atau watak tokoh dalam suatu pementasan lakon (Stanislavski, 2007). Karakter disini adalah tokoh yang hidup, bukan mati; dia dalah boneka di tangan kita karena karakter ini berpribadi, berwatak dia memiliki sifat-sifat karakteristik yang tiga dimensional, yakni dimensi Fisiologis, Sosiologis, dan Psikologis (Harrymawan, 1998). Rose Thomas adalah wanita muda berusia 22 tahun, namun nampak lebih tua seperti wanita berumur 30-an. Memiliki rambut yang hitam. Raut wajahnya seperti pecandu berat, pucat pasi dengan mata celong. Tampak liar dan berpenyakitan. Berasal dari kota lain, di Amerika. Ia datang ke New York untuk mencari pekerjaan. 
Namun karena ia tidak memiliki keterampilan apapun, ia hanya bisa menjadi pembantu rumah tangga yang harus bekerja selama 12 jam dengan gaji yang tidak seberapa. Maka dari itu ia lebih memilih untuk menjadi pelacur dijalanan. Rose tinggal di sebuah ruangan yang sangat berantakan di lantai atas sebuah perumahan bersama lelaki bernama Steve. Tapi pria itu bukanlah suaminya. Rose mempunyai anak berusia balita. Ia sedang menderita penyakit TBC yang sudah sangat parah. Steve selalu menuntut Rose untuk mencari uang yang ia pergunakan untuk mabuk-mabukan dan berjudi. Padahal Rose juga sangat membutuhkan uang untuk menyembuhkan penyakitnya.

Untuk mengetahui secara mendalam sisi psikologi tokoh Rose Thomas, dapat juga dianalisa melalui teori Psikoanalisis dari Sigmund Freud. Freud merumuskan tiga hal terpenting dari sistem kepribadian manusia yaitu Id, Ego, dan Superego (Hall, 1959). Meskipun ketiga sistem tersebut memiliki fungsi, kelengkapan, prinsipprinsip operasi, dinamisme, dan mekanismenya masing-masing. Ketiga sistem kepribadian ini saling berkaitan serta membentuk suatu totalitas. Tingkah laku manusia merupakan produk interaksi antara id, ego, dan superego itu (Koswara, 1991). Jika ketiga sistem tersebut bertentangan maka akan timbul konflik dari kepribadian manusia. Konflik ini dapat disebut konflik psikologi karakter. Aktor banyak menemukan konflik psikologis pada tokoh Rose Thomas. Kecemasan dan kekhawatiran akan keselamatan anaknya serta perlakuan kasar yang kerap ia dapatkan. Kecemasan adalah suatu pengalaman perasaan yang menyakitkan dan ditimbulkan oleh keteganganketegangan dalam alat-alat intern dari tubuh. Ketegangan ini akibat dari dorongan-dorongan dalam atau luar yang dikuasai oleh susunan syaraf yang otonom (Hall, 1959).

Steve sering melakukan perlakuan kasar terhadap Rose jika kemauannya tidak dituruti, bahkan tidak segan-segan menyakiti anaknya. Rose sangat patuh pada Steve karena itu merupakan rasa terimakasihnya, sebab Steve selama ini telah melindungi dan memberinya pekerjaan. Rose sangatlah keibuan, sangat menyayangi anaknya. Sebenarnya, Rose sangat ingin meninggalkan pekerjaannya yang sekarang ini dan ingin hidup tenang. Namun ia tidak pernah memiliki cukup uang dan ia selalu takut kalau Steve akan mencari serta membunuhnya. Ia juga berpikiran bahwa akankah ada orang yang akan menerimanya bekerja jika mereka tahu bahwa Rose adalah seorang pelacur jalanan serta berpenyakitan. Rose berada dalam posisi yang serba salah, karena anaknya yang sangat ia sayangi juga sering dijadikan kambing hitam oleh Steve. Steve sering mengancam akan menyakiti anaknya kalau Rose tidak menuruti perintahnya.

Aktor merupakan penyampai pesan dalam sebuah pertunjukan teater. Aktor adalah seniman yang mewujudkan peran lakon kedalam realita seni pertunjukan (Anirun, 1998). Sebuah pesan akan tepat disampaikan oleh tokoh jika aktor menguasai teknikbermain peran yang baik. Dalam memerankan tokoh Rose Thomas actor menggunakan pendekatan akting realis. Pendekatan akting realis merupakan akting yang berusaha menyuguhkan tingkah laku manusia melalui diri si aktor dari hasil mengerti karakter yang dimainkannya. Menciptakan sesuatu diatas panggung seperti "kenyataan" yang ada. Menciptakan ilusi diatas panggung, seolaholah penonton menyaksikan apa yang terjadi dalam kehidupan sehari-hari.

Pemeranan tokoh Rose Thomas menggunakan teori akting realis Stanislavski (2007) yang berusaha menghadirkan tingkah laku manusia secara wajar diatas panggung karena pada naskah Perangkap membicarakan persoalan tentang realitas hidup yang sering terjadi. Pada naskah ini sendiri yang dibicarakan adalah tentang penderitaan kaum yang terpinggirkan, kekerasan dan keterpaksaan. Pemeranan realis merupakan ilusi realita yang ditampilkan seolah-olah benar dan 
dapat dipercaya kebenarannya diatas panggung. Bermain benar artinya bermain tepat dan masuk akal bahkan masuk kedalam hidup tokoh tersebut dengan memainkan logika tokoh, perasaan serta pikirannya.

Seni panggung bagi Stanislavski (2007) bukanlah sekadar tiruan. Ia adalah metamorfosis. Tujuannya tidak sekedar meyakinkan tapi mencipta. Subjeknya bukanlah kehidupan akan tetapi transendensinya. Kutipan Stanislavski tersebut dapat disimpulkan bahwa berlakon bukanlah sekadar kepura-puraannya saja, namun juga mendalami kehidupan tokoh dengan cara menemukan kebiasaankebiasaan yang mungkin tokoh lakukan sehingga menjadikan seorang aktor cerdas dalam memahami manusia yang diperankannya. Teori akting realis Stanislavski sangat dibutuhkan untuk pemeranan tokoh Rose Thomas dalam naskah Perangkap karena dalam hal ini penciptaan dan pendandanan manusia baru didalam tubuh aktor membutuhkan pemahaman-pemahaman tentang fikiran dan cara hidup tokoh sebagai keberhasilan memerankan tokoh.

\section{b. Proses Penciptaan}

Proses penciptaan adalah salah satu tahapan aktor dalam mempersiapkan diri untuk menciptakan karakter yang akan dipertunjukkan kepada penonton. Bermain adalah hasil terakhir dari suatu prosedur yang panjang (Bolelavski, 1960). Bermain yang dimaksud adalah mempertunjukkan hasil yang telah didapatkan dalam proses yang sudah dilalui. Oleh karena itu proses tersebut dilakukan dalam beberapa tahap untuk kesiapan aktor dalam memerankan tokoh baik secara jasmani maupun rohani, yaitu:

\section{Siap Raga}

Proses latihan merupakan penuangan ide-ide terhadap satu objek yang akan dibahas dari beberapa pihak yang mengikutinya. Pencapaian menuju aktor yang berkualitas dapat dicapai dengan kerja keras lewat latihan secara periodik (terus menerus). Kemampuan atau bakat menjadi seorang aktor tidak mungkin meningkat apabila tidak berangkat dari proses latihan tanpa henti, latihan dengan penuh kedisiplinan. Disiplin yang dimaksud terhadap diri sendiri, baru kemudian terhadap perintah serta petunjuk instruktur. Tahap pelatihan dalam menciptakan tokoh Rose Thomas ini melalui beberapa tahapan. Seperti melakukan latihan konsentrasi, latihan dasar-dasar keaktoran, dan melatih stamina.

\section{Siap Pemahaman}

Bagian ini terdiri dari beberapa tahap yaitu tahap menganalisis, mengumpulkan referensi terkait tokoh yang diperankan dengan melakukan observasi dan wawancara serta kemudian melakukan diskusi bersama seluruh tim guna menyamakan konsep dan pemahaman naskah.

\section{Siap Sukma}

Tahapan menuju siap sukma ini terdapat beberapa teknik pelatihannya diantaranya mengolah chemistry dengan lawan main, pembiasaan terhadap apa yang menjadi kebiasaan tokoh, serta melatih penjiwaan terhadap karakter yang dimainkan.

\section{Simpulan}

Teater adalah potret sepenggal kehidupan yang diciptakan diatas panggung. Pada akting realis aktor harus mampu menghidupkan peran agar tercipta kesungguhan realita yang nyata. Menciptakan kenyataan teater, tidak semata-mata karena keinginan meniru realita namun nampaknya lebih sebagai keinginan yang lebih untuk mewujudkan alam dan mengharapkan susunan realita yang tidak kita miliki dalam hidup. Hal tersebut tentu akan membentuk kepercayaan penonton dalam menonton kesungguhan aktor dalam berlakon.

Naskah Perangkap karya Eugene O'Neill ini bercerita tentang kondisi yang sering dialami oleh orang-orang yang 
terpinggirkan. Seorang pelacur jalanan bernama Rose Thomas yang sering mendapatkan perlakuan kasar dari lelaki bernama Steve. Berlatar pada malam musim panas diawal turunnya hujan di belahan timur kota New York, Amerika Serikat. Rose sendiri adalah alat bagi Steve untuk bisa mendapatkan uang setiap harinya. Rose harus menuruti semua yang Steve katakan karena ia tidak punya pilihan, jika menolak maka anak dari Rose juga akan menjadi sasaran kemarahan Steve. Steve tidak pernah peduli pada Rose, bahkan pada penyakit TBC yang Rose derita sekalipun. Pertengkaran sudah tidak asing lagi bagi Rose dan Steve. Disisilain Rose sangat ingin pergi dari tempat itu, tapi tidak semudah membalikkan telapak tangan. Steve tidak akan membiarkannya pergi begitu saja. Kalau Rose sampai nekat pergi, Steve akan mencari dan membunuhnya. Lagipula Steve mempunyai koneksi yang sangat baik dengan para polisi dan tersebar dimana-mana. Maka tidaklah sulit untuk menemukan Rose sebelum dia bisa pergi jauh dari tempat itu. Permasalahan yang dialami oleh tokoh Rose memanglah sangat kompleks. Banyak pergolakan di dalam batinnya. Rose tidak tahu apa yang seharusnya ia lakukan.

Disaat Rose sedang sangat terpuruk dan mengalami perlakuan kasar dari Steve, muncullah sosok penyelamat. Tim Morgan, seorang buronan perampok bank yang sedang menghindari kejaran polisi. Rose sempat kebingungan dengan kedatangan Tim, namun pada akhirnya Rose dapat menerima dan merasa sangat berterimakasih. Hingga lama kelamaan Rose dan Tim saling terbuka, menceritakan kehidupan dan takdir mereka masingmasing. Tim adalah seorang penjahat, namun ia menjadi seperti ini bukanlah atas kemauannya sendiri. Perasaan saling menyukai muncul diantara Rose dan Tim. Rose merasa akan ada harapan untuk ia bisa pergi dari keadaan yang sedang menjeratnya. Tim begitu baik, begitu peduli akan apa yang dialami Rose. Namun hal yang tak terduga terjadi. Steve berhasil membunuh Tim. Rose sangat histeris mendapati kejadian ini, ketika harapan datang namun seketika itu juga ia pergi. Penderitaan Rose tidak sampai disini, perangkap yang selama ini menjeratnya telah berganti dengan perangkap yang lain. Rose menjadi tertuduh atas terbunuhnya Tim, ia diringkus dan dijebloskan kedalam penjara.

Dalam pementasan ini aktor ingin beraksi secara wajar dengan membawakan naskah yang mengangkat konflik dalam kehidupan sosial. Menurut seniman realisme, sesuatu harus dilihat atau dilukiskan menurut keadaan yang sesungguhnya. Dengan demikian mereka mengamati sesuatu dengan kacamata objektif, tidak boleh dengan sengaja diindah-indahkan atau tidak boleh pula dibuat lebih buruk. Saat ini, banyak aktor yang beraksi hanya sekedar untuk terlihat indah di mata penonton tanpa memperhatikan kedalaman karakter pada tokoh yang diperankannya.

Untuk memerankan tokoh dalam sebuah naskah realis tentu membutuhkan analisis terlebih dahulu, agar dapat diketahui bagaimana seluk beluk mengenai tokoh yang akan diperankannya. Seorang aktor harus mempelajari karakter manusia lain yang sama sekali berbeda dengan dirinya. Dengan cara ini, maka akan terungkap bagaimana latar belakang, kebiasaan tokoh, apa yang sedang menjadi pikirannya, dan hal-hal lain yang menjadi acuan aktor untuk menjadi tokoh yang diperankan.

Untuk pemeranannya, aktor menggunakan metode akting realis Stanislavski (2007). Akting realis, yakni akting yang berusaha menyuguhkan tingkah laku manusia melalui diri si aktor dari hasil mengerti karakter yang dimainkannya. Menciptakan sesuatu diatas panggung seperti "kenyataan" yang ada. Menciptakan ilusi diatas panggung, seolaholah penonton menyaksikan apa yang terjadi dalam kehidupan sehari-hari. Ilusi tentang kenyataan yang terdapat dalam 
masyarakat yang kemudian "dipindah" diatas panggung.

Kemudian, proses penciptaan adalah salah satu tahapan aktor dalam mempersiapkan diri untuk menciptakan karakter yang akan dipertunjukkan kepada penonton. Oleh karena itu proses tersebut dilakukan dalam beberapa tahap yang harus dilalui.

\section{Daftar Pustaka}

Anirun, S. (1998). Menjadi Aktor. Bandung: Rekamedia Multipraka.

Anwar, C. (2005). Drama Bentuk - Gaya dan Aliran. Yogyakarta: Elkaphi.

Bolelavski. (1960). Enam Pelajaran Pertama Bagi Calon Aktor (Sani, A., Trans.). Jakarta: Usaha Penerbit Djaja Sakti.

Endraswara, S. (2014). Metode Pembelajaran Drama. Yogyakarta: CAPS.

Harrop, J., \& Epstein, S.R. (2010). Acting With Style (Yudiaryani, Trans.). Yogyakarta: Institut Seni Indonesia Yogyakarta.
Harymawan, R. M. A. (1998). Dramaturgi. Bandung: PT. Remaja Rosdakarya. Indonesia.

Mitter, S. (2002). Sistem Pelatihan Lakon Stanislavski, Brecht, Grotowski dan Brook (Yudiaryani, Trans.). Yogyakarta: Arti.

O’Neill, E. (n.d.). Perangkap (terjemahan Faried W. Abe).

Pease, A. (1993). Bahasa Tubuh. Jakarta: Arcan.

Pratiwi, Y., \& Siswiyanti, F. (2014). Teori Drama dan Pembelajarannya. Yogyakarta: Ombak.

Sitorus, E.D. (2003). The Art Of Acting "Seni Peran Untuk Teater, Film \& $T V$ ”. Jakarta: Gramedia Pustaka Utama.

Stanislavski, K. (2008). Membangun Tokoh. Jakarta: KPG (Kepustakaan Populer Gramedia).

Stanislavski, K. (2007). Persiapan Seorang Aktor. Bandung: PT. Bastela Indah Prinindo.

Hall, C. S. (1959). Suatu Pengantar dalam Ilmu Jiwa Sigmund Freud. Bandung: Pembangunan. 